\title{
Systematics, functional morphology and distribution of a bivalve (Apachecorbula muriatica gen. et sp. nov.) from the rim of the 'Valdivia Deep' brine pool in the Red Sea
}

\author{
P. GRAHAM OLIVER ${ }^{1}$, HEGE VESTHEIM ${ }^{2}$, ANDRÉ ANTUNES ${ }^{3}$ AND STEIN KAARTVEDT ${ }^{2}$ \\ ${ }^{1}$ National Museum of Wales, Cathays Pk., Cardiff CF10 3 NP, Wales, UK, ${ }^{2}$ King Abdullah University of Science and Technology, Red \\ Sea Research Center, Thuwal 23955-6900, Saudi Arabia, ${ }^{3}$ IBB - Institute for Biotechnology and Bioengineering, Centre of Biological \\ Engineering, Micoteca da Universidade do Minho, University of Minho, Braga, Portugal
}

\begin{abstract}
The deep brine pools of the Red Sea comprise extreme, inhospitable habitats yet house microbial communities that potentially may fuel adjacent fauna. We here describe a novel bivalve from a deep-sea $(1525 \mathrm{~m})$ brine pool in the Red Sea, where conditions of high salinity, lowered $\mathrm{pH}$, partial anoxia and high temperatures are prevalent. Remotely operated vehicle $(R O V)$ footage showed that the bivalves were present in a narrow $(20 \mathrm{~cm})$ band along the rim of the brine pool, suggesting that it is not only tolerant of such extreme conditions but is also limited to them. The bivalve is a member of the Corbulidae and named Apachecorbula muriatica gen. et sp. nov. The shell is atypical of the family in being modioliform and thin. The semi-infaunal habit is seen in ROV images and reflected in the anatomy by the lack of siphons. The ctenidia are large and typical of a suspension feeding bivalve, but the absence of 'guard cilia' and the greatly reduced labial palps suggest that it is non-selective as a response to low food availability. It is proposed that the low body mass observed is a consequence of the extreme habitat and low food availability. It is postulated that the observed morphology of Apachecorbula is a result of paedomorphosis driven by the effects of the extreme environment on growth but is in part mitigated by the absence of high predation pressures.
\end{abstract}

Keywords: Corbulidae, deep-hyper-saline anoxic basins (DHABs), Red Sea, deep-sea, Apachecorbula gen. nov., functional morphology, Valdivia Deep, deep-sea bivalves

Submitted 12 May 2014; accepted 23 July 2014; first published online 11 November 2014

\section{INTRDDUCTION}

Deep-sea anoxic brine pools are formed by the solution of evaporite deposits and the stable accumulation of these hypersaline solutions in enclosed depressions on the sea floor (Bischoff, 1969; Hartmann, 1985). They are known from the Gulf of Mexico (Cordes et al., 2010), eastern Mediterranean, and are widespread in the Red Sea with 25 known to date (Antunes et al., 2011). The brine pools are both highly saline and usually anoxic. In addition to having a high metal content and low $\mathrm{pH}$ they harbour a unique microbial community of extremophiles (Antunes et al., 2011). Metazoans are absent from the extremes of anoxia but in the Red Sea have been recorded from the margins of a shallow and less saline site (Thuwal Seeps) (Batang et al., 2012) as well as along the margins of the Kebrit brine pool (Vestheim and Kaartvedt, in preparation). Bivalve molluscs including a species of Corbuloidea were recorded from the Thuwal Seeps but these have not been

Corresponding author:

P.G. Oliver

Email: graham.oliver@museumwales.ac.uk studied beyond a tentative identification (Corbula cf. rotalis) due to lack of samples (Batang et al., 2012). The presence of bacterial mats at the Thuwal Seeps suggests that this is an active cold seep site. In the Gulf of Mexico dense beds of the chemosymbiotic Bathymodiolus childressi (Gustafson et al., 1998) are found around the margins of a cold seep brine pool (MacDonald et al., 1990). In the eastern Mediterranean meiofaunal communities have been found in hypersaline sediments with sparse macrofauna at the margins. Juvenile bivalves were found in the meiofaunal samples but were not identified (Lampadariou et al., 2003).

In April 2013 the Valdivia Deep brine pool, situated in the central Red Sea $\left(21^{\circ} 20^{\prime} 49^{\prime \prime} \mathrm{N} 37^{\circ} 57^{\prime} 19^{\prime \prime} \mathrm{E}\right)$ (Figure 1) at a depth of $1525 \mathrm{~m}$ was investigated by an expedition from the King Abdullah University of Science and Technology. Video footage from a ROV revealed small, dark-coloured bivalves along the margins of the brine pool. The bivalves were sampled for further investigation together with analyses of environmental conditions, and proved to be a novel genus and species. The Valdivia bivalves are living in conditions of high salinity, low oxygen, lowered $\mathrm{pH}$ and relatively high temperatures. This paper addresses their identity and systematic relationships and explores their functional morphology in relation to the extreme environmental conditions in which they are found. 


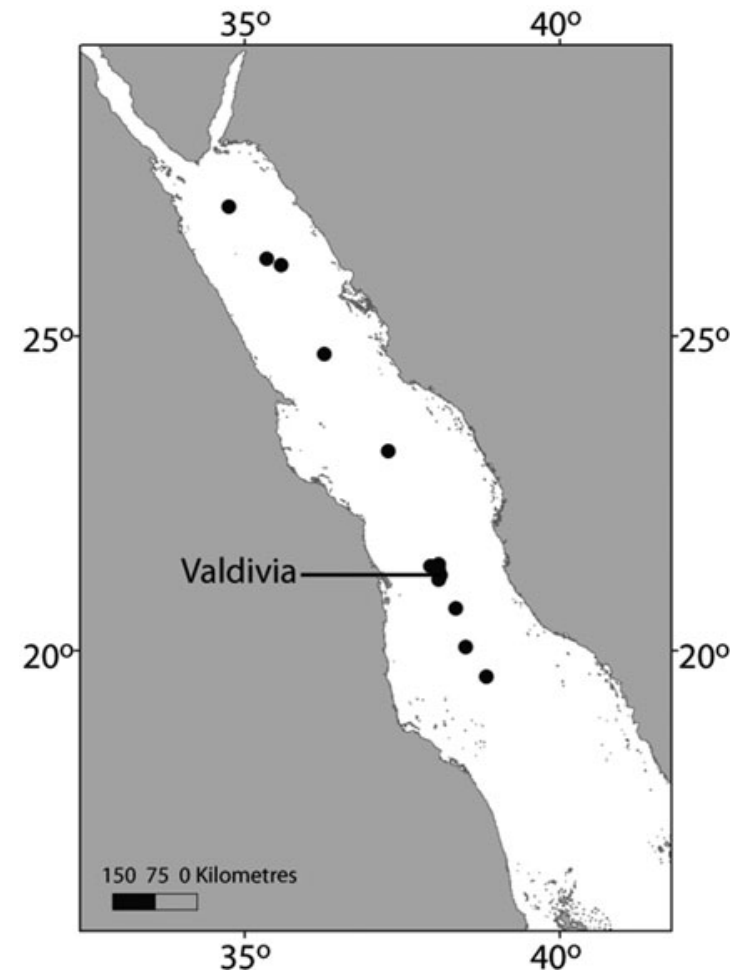

Fig. 1. Distribution of the major brine pools in the Red Sea.

\section{MATERIALS AND METHODS}

Data were collected in April 2013, using the RV 'Aegaeo' (4th King Abdullah University of Science and Technology (KAUST) Red Sea Expedition).

\section{Environment}

Data on temperature, $\mathrm{pH}$, salinity and oxygen were collected using a specially designed CTD, able to withstand the corrosive brine environment. The instrument package also included probes for measuring oxygen and $\mathrm{pH}$.

\section{Underwater observation, collection and preservation}

Underwater observations were conducted using the ROV Max Rover (DSSI, USA) system as described in Batang et al. (2012). Sediment samples were collected using the ROV's robotic arm fitted with a fabric bag. The samples were then transferred to the surface in the bag and immediately inspected in the ship's laboratory. Individual bivalves were picked out and either frozen in $\mathrm{N}_{2}$ (l) or preserved in ethanol (70\%), glutaraldehyde (EM grade) or $4 \%$ buffered formaldehyde solution section. Preserved samples were stored at $4{ }^{\circ} \mathrm{C}$ upon analysis.

No live macrofauna except for the corbulid bivalves were found in the sediments. The sediment mainly consisted of biogenic material being remains of shelled pelagic snails (pteropods) and some calcified foraminiferans along with mineral particles.

\section{Morphology}

Morphology was examined by gross dissection following staining of tissues in haematoxylin. Scanning electron microscopy of tissues followed dehydration in 100\% ethanol and critical-point drying, gold coating and microscopy with a Jeol Neoscope; shell micrographs were taken on a FEI Quanta 200 or Jeol Neoscope. Shells were examined without cleaning and following cleaning with dilute bleach. The terminology associated with hinge structures follows that of Anderson \& Roopnarine (2003).

\section{Molecular data and analysis}

In order to confirm the family placement and ascertain affinities within the Corbulidae a molecular analysis was carried out. Total genomic DNA was extracted from 10 ethanolpreserved specimens using the DNA Easy Blood and Tissue Kit (Qiagen) following the manufacturer's protocol for animal tissue. DNA yield of the extractions was quantified on a Qubit 2.0 fluorometer (Invitrogen) and partial COI, $28 \mathrm{~S}, 18 \mathrm{~S}$ and $16 \mathrm{~S}$ sequences were generated by PCR using the primer pairs as described in Table 1 . The $25 \mu$ PCR reactions included $5 \mu \mathrm{l} 5 \mathrm{X}$ Phusion buffer, $0.5 \mu \mathrm{l} 10 \mathrm{mM}$ dNTPs, $1.25 \mu \mathrm{l}$ each primer $(10 \mu \mathrm{M}), 1.25 \mu \mathrm{l} 50 \mathrm{mM} \mathrm{MgCl}, 0.125 \mu \mathrm{l}$ Phusion High-Fidelity DNA polymerase and $1 \mu$ DNA extract $\left(\sim 10 \mathrm{ng}^{-1}\right)$. Thermal cycling conditions were: $98^{\circ} \mathrm{C}$ for $2 \mathrm{~min}$, then 37 cycles of $98^{\circ} \mathrm{C}$ for $30 \mathrm{~s}, 30-40 \mathrm{~s}$ at annealing temperature (see Table 1 ) and $72^{\circ} \mathrm{C}$ for $1 \mathrm{~min}$, followed by a final extension $10 \mathrm{~min}$ at $72^{\circ} \mathrm{C}$. A negative (no template DNA) and positive control (template DNA known to amplify) were included in all PCRs. All PCR products were checked on a $1 \%$ agarose gel and cleaned with Illustra ExoStar 1-Step (GE Healthcare) before sequenced on an ABI 3730xl Capillary Sequencer (Applied Biosystems) using the respectively forward and backward PCR primer.

Contiguous sequences were, after manual inspection, compared with other corbulid sequences. No other, appropriately preserved, corbulids from the Red Sea were available for molecular analysis and all comparisons were made from previously published DNA sequences available through GenBank and from Anders Hallan (Hallan et al., 2013). There was only one $16 \mathrm{~S}$ (Corbula tunicata $\mathrm{KC}_{429314}$, partial sequence, not overlapping) and no COI sequences from closely related corbulids available for comparison at the time of analysis, hence phylogenetic analysis for those genes were not performed. For $28 \mathrm{~S}$ and $18 \mathrm{~S}$ sequences phylogenetic analysis was executed on the Phylogeny.fr platform (Dereeper et al., 2008) using a MUSCLE alignment (Edgar, 2004), GBLOCKS curation of the nucleotide alignment allowing gaps in the final alignment

Table 1. List of PCR primers used in this study.

\begin{tabular}{llll}
\hline Primer pair & Target & $\begin{array}{l}\text { Annealing } \\
\text { temperature }\end{array}$ & Reference \\
\hline $\begin{array}{l}\mathrm{LCO} 1490 / \\
\mathrm{HCO} 2198\end{array}$ & $\mathrm{COI}$ & $50^{\circ} \mathrm{C}$ & Folmer et al. $(1994)$ \\
$\begin{array}{l}16 \mathrm{Sa} / 16 \mathrm{Sb} \\
3 \mathrm{~F} / 18 \mathrm{sbi}, 1 \mathrm{~F} / 5 \mathrm{R},\end{array}$ & $18 \mathrm{~S}$ & $50^{\circ} \mathrm{C}$ & $\begin{array}{c}\text { Xiong \& Kocher } \\
(1991)\end{array}$ \\
$\begin{array}{l}18 \mathrm{Sa} 2.0 / 9 \mathrm{R} \\
\mathrm{C} 1 / \mathrm{C} 4\end{array}$ & $28 \mathrm{~S}$ & $52^{\circ} \mathrm{C}$ & $\begin{array}{c}\text { Giribet } \text { et al. }(1996), \\
\text { Whiting } \text { et al. }(1997) \\
\text { Lorion } \text { et al. }(2010)\end{array}$ \\
\hline
\end{tabular}




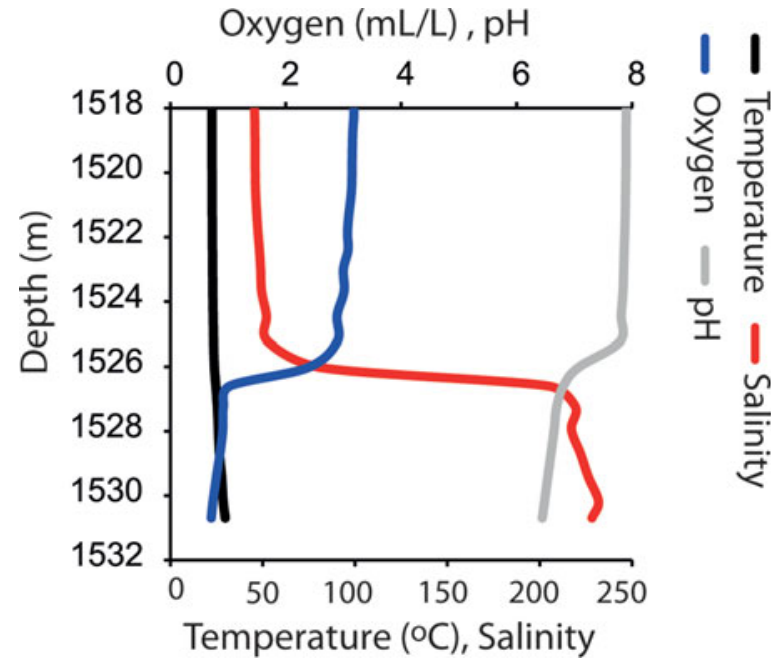

Fig. 2. Chart of salinity, dissolved oxygen, $\mathrm{pH}$ and temperature with increasing depth in proximity to the Valdivia brine pool.

Table 2. CTD data for a depth range of 1525-1530 $\mathrm{m}$ indicating rapid and significant changes in salinity, dissolved oxygen, $\mathrm{pH}$ and temperature.

\begin{tabular}{lllll}
\hline Water depth $(\mathbf{m})$ & Temperature $\left({ }^{\circ} \mathbf{C}\right)$ & $\mathbf{p H}$ & Salinity & Oxygen $\left(\mathbf{m g ~ l}^{-\mathbf{1}}\right)$ \\
\hline 1525.2 & 23.4 & 7.8 & 53 & 2.9 \\
1526.0 & 23.9 & 7.1 & 82 & 2.4 \\
1526.6 & 24.7 & 6.8 & 205 & 1.0 \\
1527.2 & 25.5 & 6.7 & 219 & 0.9 \\
1527.9 & 26.0 & 6.7 & 217 & 0.9 \\
1528.7 & 26.6 & 6.6 & 222 & 0.8 \\
1529.4 & 27.8 & 6.5 & 226 & 0.8 \\
1530.2 & 28.7 & 6.5 & 231 & 0.7 \\
\hline
\end{tabular}

(Castresana, 2000), the PhyML phylogeny package (Guindon \& Gascuel, 2003) and the HKY85 nucleotide substitution model with approximate likelihood-ratio test for branch support (Anisimova \& Gascuel, 2006). Tree rendering was performed with TreeDyn (Chevenet et al., 2006).

\section{RESULTS}

\section{Environmental conditions}

Vertical profiles of temperature, salinity, dissolved oxygen and $\mathrm{pH}$ were almost constant with depth until close proximity to the surface of the brine pool. Within a $5 \mathrm{~m}$ zone the water quality parameters change rapidly and significantly (Figure 2, Table 2). At $1525 \mathrm{~m}$ the salinity is $53 \%$ but within a further $2 \mathrm{~m}$ depth it has risen to $220 \%$. Similar rapid changes in environmental parameters over this $2 \mathrm{~m}$ range are seen in dissolved oxygen dropping from 2.9 to $0.9 \mathrm{mg} \mathrm{l}^{-1}$; $\mathrm{pH}$ dropping from 7.8 to 6.5 while water temperature rises from $23.4-26.1^{\circ} \mathrm{C}$.

\section{Video footage}

Video footage from the ROV revealed a barren fringe around the brine pool except for small, dark-coloured bivalves living half buried in the sediment (Figure $3 \mathrm{~A}-\mathrm{C}$ ). The band of bivalves could be seen stretching into the distance (Figure $3 \mathrm{C}$ ). The ROV footage showed that the bivalves were present in a narrow $(20 \mathrm{~cm})$ band along the edges of the Valdivia Deep. The bivalves seemed to sit on the hill tops, not in the valleys (topographic depressions) suggesting that they are responding closely to changes in water chemistry. Counting one site (frame) gave an estimate of 130 individuals within a $70 \times 20 \mathrm{~cm}$ area, though the distribution was patchy. This high density corresponds to approximately 900 individuals $\mathrm{m}^{-2}$. The distribution within a narrow band suggests that the bivalve is not only tolerant of the extreme conditions but is also limited to them. This is unlike Bathymodiolus childressi which tolerates hypersalinity but is not restricted to such environments (Carney et al., 2006).

No other live metazoans were observed in the sediments collected with the bivalves, which therefore seem quite unique in inhabiting the sediment along the edges of the Valdivia Deep. There was no evidence of a chemosynthetic community such as that seen at the Thuwal Seeps where
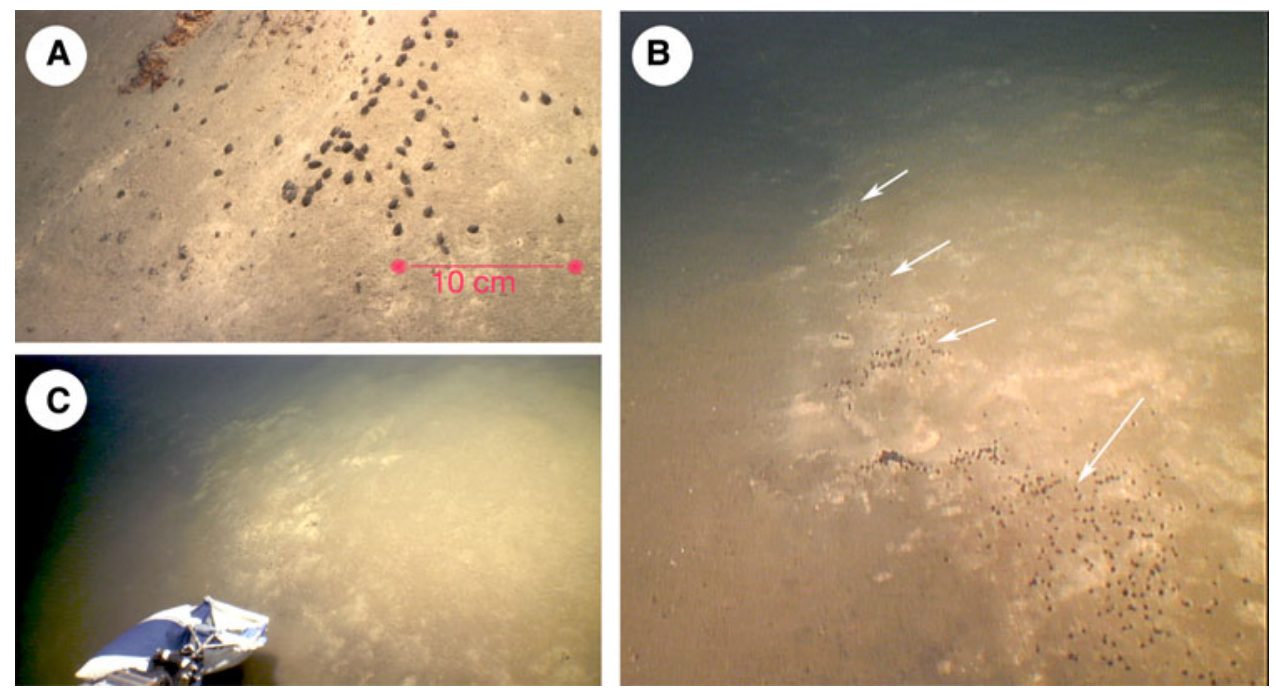

Fig. 3. Sea floor images at the margins of the Valdivia brine pool taken by the ROV Max Rover. Apachecorbula appear as black coloured bivalves in (A) and as small black objects arranged in a narrow band in (C). (B) shows the collecting bag of the ROV. 


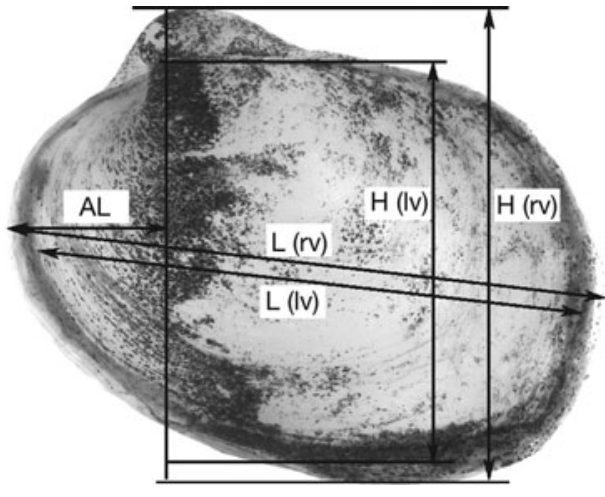

Fig. 4. Diagram showing the shell measurements used in the description.

bacterial mats and dense communities of invertebrates were observed (Batang et al., 2012). This is in keeping with the lack of hydrothermal activity at the Valdivia Deep reported by Zierenberg \& Shanks (1986).

\section{Phylogenetics}

There was no intraspecific variation among the bivalve individuals sequenced. Representative, contiguous sequences have been deposited to EMBL database under the accession numbers HG942537 (COI), HG942542 (16S), HG942541 (18S) and HG942543 (28S). Based on comparison of $18 \mathrm{~S}$ and $28 \mathrm{~S}$ partial sequences (data not shown), the Valdivia bivalve fits within the 'Western pacific group' of Hallan et al. (2013) that includes Caryocorbula coxi Pilsbry, 1897 and Caryocorbula? zelandica Quoy \& Gaimard, 1835 'Corbula sinensis' Bernard et al., 1993, Notocorbula hydropica as well as 'Notocorbula coxi' (AY192684, misidentified in GenBank (Hallan et al., 2013)) and Corbula gibba Olivi, 1792. The sequences available were not informative enough to conclude anything more on the phylogenetic relationship to these species.

\section{TAXDNDMY}

SYSTEMATICS

Bivalvia Linnaeus, 1758

Heterodonta Neumayr, 1884

Order Myoida Stoliczka, 1870

Superfamily Myoidea Lamarck, 1809

Family Corbulidae Lamarck, 1818

Genus Apachecorbula Oliver \& Vestheim, gen. nov.

Type species: A. muriatica Oliver \& Vestheim, this paper, monotypic

\section{DEFINITION}

Small, thin, translucent shelled, slightly inequivalve, strongly inequilateral, prosogyre beaks close to the anterior. Outline obliquely oval, modioliform. Hinge weak, right valve with a single anterior cardinal and a thin posterior flange; left valve with a cardinal complex of a cardinal socket, median projecting

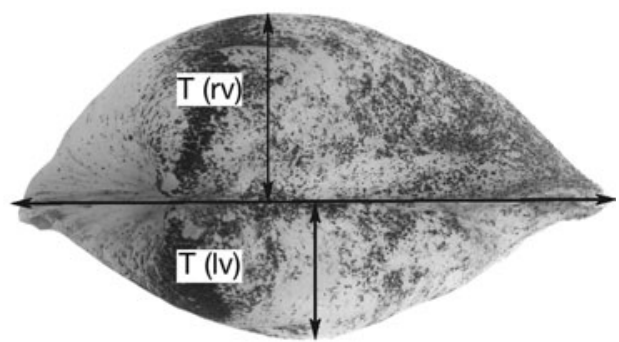

chondrophore and a small projecting knob behind the chondrophore; a narrow posterior flange also present.

\section{ETYMOLOGY}

From the Greek apaches meaning 'without thickness' (Brown, 1956); referring to the thin shell and insubstantial soft tissues.

\section{COMPARISONS}

There are few systematic studies of the Corbulidae but that of Anderson \& Roopnarine (2003) lists 40 genera of which 14 are extant, of these only seven have an Indo-Pacific distribution. A recent study by Hallan et al. (2013) presented the most comprehensive molecular-based study to date and indicated that, for the marine genera included, the clades corresponded poorly with shell-based genera. However, in general the marine Corbulidae have thick shells and are distinctly inequivalve. Two main shell forms are exhibited: (1) inflated, trigonal, posterior narrowly rostrate; (2) subovate, posterior narrow, subtruncate. In the Red Sea the former is represented by Corbula (Varicorbula) erythraeenisis Adams, 1871 and the latter by Corbula (Anisocorbula) sulculosa Adams, 1870. The thin, slightly inequivalve and modioliform shell from the 'Valdivia Deep' is not seen in any of the described genera. The molecular study confirmed the placement within the Corbulidae and showed that Apachecorbula has closer affinity with other Indo-Pacific genera than those from the Western Atlantic/Caribbean. This distinction between the corbulids of the two regions was first noted by Anderson \& Roopnarine (2003) and reiterated by Hallan et al. (2013).

Apachecorbula muriatica Oliver \& Vestheim, gen. et sp. nov.

\section{MATERIAL EXAMINED}

40 specimens, Valdivia Brine Pool, Red Sea, $21^{\circ} 2049$ N $37^{\circ} 57$ 19 E, 1525 m. RV 'Aegaeo', 2013 KAUST Red Sea Expedition, 12/iv/2013.

Holotype, 1 specimen, as above. NMWZ 2013.058.1.

Paratypes, 10 specimens as holotype, NMWZ 2013.058.2; remaining specimens as holotype KAUST.

\section{COMPARATIVE MATERIAL EXAMINED}

Corbula (Varicorbula) sp. 1. 8 shells, Central Red Sea, RV 'Valdivia' station $741 \mathrm{GKW}, 24^{\circ} 43.100 \mathrm{~N} 36^{\circ} 15.500 \quad \mathrm{E}$, 1465 m. 08/03/1981. Senckenberg-Museum. 
Corbula (Varicorbula) erythraeensis. 20 shells, Gulf of Suez, Red Sea, ex Macandrew, National Museum of Wales, Melvill-Tomlin Coll. NMW. 1955.158. 4 spec. Ras Budran Oilfield, Gulf of Suez, $28^{\circ} 57 \mathrm{~N} 33^{\circ} 10$ E, ex Oil Pollution Rsearch Unit/JP Hartley, 1980-1983, NMWZ 1982.068.

Corbula (Anisocorbula) sulculosa. 20+ specimens, Ras Budran Oilfield, Gulf of Suez, $28^{\circ} 57 \mathrm{~N} 33^{\circ} 10$ E, ex Oil Pollution Research Unit/JP Hartley, 1980-1983, NMWZ 1982.068

Corbula (Anisocorbula) taitensis 2 shells, Masirah, Oman, Arabian Sea, $20^{\circ} 12 \mathrm{~N} 58^{\circ} 42 \mathrm{E}$, NMWZ 1993.61.1282.

Corbula (Varicorbula) rotalis. 10 shells, Hizen, Japan, Melvill-Tomlin Coll. NMW.1955.158.

Corbua (Varicorbula) gibba [Type species of Varicorbula]. Many specimens in collection of NMW from locations around the British Isles. Juveniles from the Irish Sea, NMWZ.2005.015.

Corbula sulcata [Type species of Corbula] 3 shells, Senegal, West Africa, ex Caziot, Melvill-Tomlin Coll. NMW.1955.158.

Corbula (Anisocorbula) macgillivrayi [Type species of Anisocorbula] 1 shell, Australia, Melvill-Tomlin Coll. NMW.1955.158 (Table 3).
DESCRIPTION - SHELL FIGURES $5-7$

To $9 \mathrm{~mm}$ in length. Typical shell as represented by the holotype (Figure 5) very thin, approximately $16 \mu \mathrm{m}$ in cross section (Figure $7 \mathrm{~A}$ ), translucent, fragile. Inequivalve, left valve the slightly smaller, slightly less inflated fitting inside the larger right valve. Outline inequilateral, prosogyrous beaks in the anterior fifth. Outline obliquely oval, modioliform, anterior narrowly rounded, posterior expanded, subtruncate. Umbonal - posterior ventral angle distinct but low, more strongly expressed in the right valve. Hinge weak, LV (Figure 6A, B) with a cardinal complex of a median narrow chondrophore (ch), posterior to it a small projecting knob $(\mathrm{kn})$, anterior to it a socket for the cardinal tooth in the RV (c sk). RV (Figure 6C) with a small cardinal peg-like tooth ( $c$ th) widely separated from an elongate, thin, submarginal posterior, weakly serrated, flange (Figure 6D). Internal ligament attached to chondrophore and subumbonal gap, external ligament short, thin (Figure 6A, B, ext lig).

Sculpture weak, without magnification smooth with weak incremental lines except for the margins of the RV of larger specimens where commarginal ridges develop and are best

Table 3. Apachecorbula muriatica sp. nov. Measurements ( $\mathrm{mm}$ ) as illustrated in Figure 4 (bk, broken; ds, disarticulated shell).

\begin{tabular}{|c|c|c|c|c|c|c|c|c|c|}
\hline & Preservation & L (rv) & L (lv) & H (rv) & H (lv) & T (rv) & T (lv) & Total T & AL \\
\hline $1 \mathrm{~A}$ & $100 \%$ Eth & 6.2 & 5.9 & 5 & 4.8 & 1.6 & 1.5 & 3.2 & 1.7 \\
\hline $1 \mathrm{~B}$ & $100 \%$ Eth & 6 & 5.7 & 4.7 & 4.4 & 2 & 1.1 & 3.1 & 1.5 \\
\hline${ }_{1} \mathrm{C}$ & $100 \%$ Eth & 5.7 & $5 \cdot 3$ & 4.6 & 4.2 & 1.8 & 1.3 & 3.1 & 1.2 \\
\hline $1 \mathrm{D}$ & $100 \%$ Eth & 5.4 & 4.9 & 4.6 & 4 & 2 & 1.6 & 3.6 & 1.4 \\
\hline $1 \mathrm{E}$ & $100 \%$ Eth & 5.6 & $5 \cdot 3$ & 5.4 & 5.7 & bk & bk & bk & 1.6 \\
\hline $2 \mathrm{~A}$ & Form to $80 \%$ Eth & 4.9 & 4.7 & 3.8 & 3.6 & 1.6 & 1 & 2.6 & 1.3 \\
\hline $2 \mathrm{~B}$ & Form to $80 \%$ Eth & 4.9 & 4.6 & 4 & 3.7 & 1.5 & 1.2 & 2.7 & 1.2 \\
\hline${ }_{2} \mathrm{C}$ & Form to $80 \%$ Eth & bk & bk & bk & bk & bk & bk & bk & bk \\
\hline $2 \mathrm{D}$ & Form to $80 \%$ Eth & 5.7 & 5.4 & 4.7 & 4.5 & bk & bk & bk & 1.3 \\
\hline $2 \mathrm{E}$ & Form to $80 \%$ Eth & 4.6 & 4.4 & 3.8 & 3.5 & 1.3 & 1.2 & 2.5 & 1 \\
\hline $3 \mathrm{~A}$ & Form to $80 \%$ Eth & 5.4 & 5.1 & 4.4 & 4 & 1.8 & 1.4 & 3.2 & 1 \\
\hline${ }_{3} \mathrm{~B}$ & Form to $80 \%$ Eth & 4.7 & 4.4 & 3.8 & 3.5 & 1.5 & 1.1 & 2.6 & 1 \\
\hline${ }_{3} \mathrm{C}$ & Form to $80 \%$ Eth & $5 \cdot 3$ & 5.2 & 4.4 & $4 \cdot 3$ & 1.7 & 1.3 & 3 & 1.2 \\
\hline $3 \mathrm{D}$ & Form to $80 \%$ Eth & 5.6 & 5.2 & 4.5 & 4.1 & 1.5 & 1.2 & 2.7 & 1.2 \\
\hline${ }_{3} \mathrm{E}$ & Form to $80 \%$ Eth & $5 \cdot 3$ & 5 & 4.2 & 3.7 & 1.8 & 1.2 & 3 & 1 \\
\hline $4 \mathrm{~A}$ & Form to $80 \%$ Eth & 5.1 & 4.8 & 4.2 & 3.9 & 1.7 & 1.6 & $3 \cdot 3$ & 1.2 \\
\hline $4 \mathrm{~B}$ & Form to $80 \%$ Eth & 5 & 4.7 & 4.1 & 3.6 & 1.6 & 1 & 2.7 & 1.3 \\
\hline $4 \mathrm{C}$ & Form to $80 \%$ Eth & 5.1 & 4.8 & 4 & 3.4 & 1.5 & 1.2 & 2.7 & 0.9 \\
\hline $4 \mathrm{D}$ & Glut to $80 \%$ Eth & 6.1 & 5.7 & 4.7 & $4 \cdot 3$ & 1.6 & 1.5 & 3.1 & 1.4 \\
\hline${ }_{4} \mathrm{E}$ & Glut to $80 \%$ Eth & 5.6 & 5.2 & $4 \cdot 3$ & $3 \cdot 7$ & 1.7 & 1.4 & 3.1 & 1.3 \\
\hline $5 \mathrm{~A}$ & Glut to $80 \%$ Eth & 5.4 & 5.1 & $4 \cdot 3$ & 3.7 & 1.9 & 1.2 & 3.1 & 1.4 \\
\hline${ }_{5} \mathrm{~B}$ & Glut to $80 \%$ Eth & 4 & 3.9 & 3.2 & 2.8 & 1.2 & 1 & 2.2 & 0.9 \\
\hline${ }_{5} \mathrm{C}$ & Glut to $80 \%$ Eth & 5.6 & $5 \cdot 3$ & 4.2 & 3.8 & 1.8 & 1.3 & 3.1 & 1.2 \\
\hline $5 \mathrm{D}$ & Glut to $80 \%$ Eth & 4.6 & 4.2 & 4.1 & 3.6 & 1.5 & 1.1 & 2.6 & 1.1 \\
\hline${ }_{5} \mathrm{E}$ & Glut to $80 \%$ Eth & 5.2 & 4.8 & 4.1 & 3.5 & 1.6 & 1.3 & 2.9 & 1.1 \\
\hline $6 \mathrm{~A}$ & Glut to $80 \%$ Eth & 5.5 & 5.2 & 4.2 & $3 \cdot 5$ & 1.8 & 1.3 & 3.1 & 1.1 \\
\hline $6 \mathrm{~B}$ & Glut to $80 \%$ Eth & $4 \cdot 3$ & 4.1 & 3.5 & 3.2 & 1.4 & 1.3 & 2.7 & 0.9 \\
\hline $6 \mathrm{C}$ & Glut to $80 \%$ Eth & 4.2 & 4.1 & 3.4 & 3.1 & 1.3 & 1 & 2.3 & 0.8 \\
\hline $6 \mathrm{D}$ & Glut to $80 \%$ Eth & 4.4 & 4.1 & 3.6 & 3.2 & 1.5 & 1.1 & 2.6 & 0.9 \\
\hline $6 \mathrm{E}$ & Glut to $80 \%$ Eth & 5.2 & 4.9 & $4 \cdot 3$ & 3.8 & 1.6 & 1.4 & 3 & 1.5 \\
\hline $7 \mathrm{~A}$ & Glut to $80 \%$ Eth & 4.8 & 4.5 & 3.9 & 3.5 & 1.6 & 1.3 & 2.9 & 1.2 \\
\hline $7 \mathrm{~B}$ & Glut to $80 \%$ Eth & 4.1 & 3.9 & 3.6 & 3.1 & 1.3 & 0.8 & 2.1 & 0.8 \\
\hline $7 \mathrm{C}$ & Glut to $80 \%$ Eth & 4.4 & 4.2 & 3.7 & 3.2 & 1.6 & 1 & 2.6 & 1.1 \\
\hline $7 \mathrm{D}$ & Glut to $80 \%$ Eth & bk & bk & bk & bk & bk & bk & bk & bk \\
\hline $7 \mathrm{E}$ & Glut to $80 \%$ Eth & bk & bk & bk & bk & bk & bk & bk & bk \\
\hline $8 \mathrm{~A}$ & Glut to $80 \%$ Eth & bk & bk & bk & bk & bk & bk & bk & bk \\
\hline HOLOTYPE & DRY & 5.8 & 5.6 & 4.7 & 4.4 & ds & ds & ds & 1.4 \\
\hline SEM & DRY GOLD & 9.2 & 8.7 & 6.9 & 6.2 & ds & ds & ds & 1.6 \\
\hline
\end{tabular}




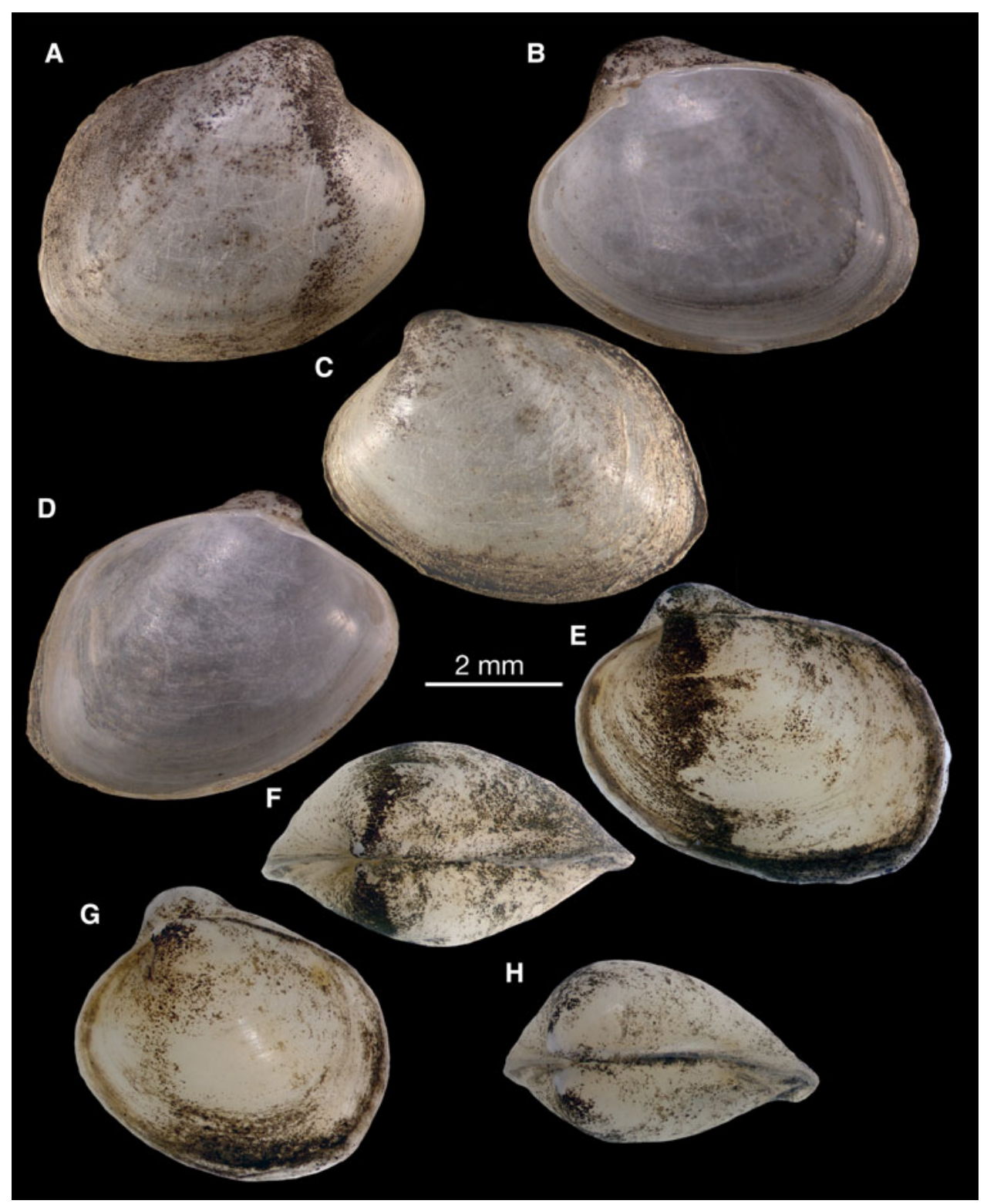

Fig. 5. Shells of Apachecorbula muriatica gen. et sp. nov. (A-D) Holotype, NMWZ. 2013.058.1. (E-H) Variations in outline and tumidity.

seen with SEM (Figure 6G). Under the SEM both valves with radial and commarginal creasing of the periostracum (Figure 6E), this reflected only very lightly as shell sculpture (Figure $6 \mathrm{H}$, circled). LV with increasing lamellar periostracum at the margins with sparse radial creases (Figure 6F). Indications of shell spines on the dorsal margin of the RV (Figure 6I, arrowed).

Shell colourless with sparse, black deposits. Deposits composed of aggregated spherules, with a compact reticulate surface (Figure $7 \mathrm{~B}, \mathrm{C}$ ).

\section{Variation}

The shape of the shell is occasionally variable. Some shells are far less inequilateral and have a more rounded appearance (Figure $5 \mathrm{G}$ ) while some although strongly inequilateral have a more rounded posterior outline (Figure ${ }_{5} \mathrm{E}$ ). This variability can be expressed in the 'length:height' ratio of the right valves while there is a mean of 1.23 and a range from 1.04-1.33. The inequilateral condition expressed as the ratio length:anterior length' has a mean of 4.47 and a range from 3.47 to 5.67 . The extent of the inequivalve condition is also variable, while the mean ratio for right and left valve tumidity is 1.33 , the range is from 1.06 to 1.82 .

\section{DESCRIPTION - ANATOMY FIGURES $7 \& 8$}

The mantle edge is thin (Figure $8 \mathrm{~B}$ ) and largely fused except for an anterior pedal aperture (Figure $8 \mathrm{~A}, \mathrm{pg}$ ) and small posterior inhalant and exhalant apertures (Figure 8A, ex, in). The musculature of the posterior apertures is weak and siphons are not developed (Figure 8C). The inner edge of the inhalant aperture bears minute widely spaced pointed papillae and a few papillae are also present on the outer edges (Figure 8C). The exhalant aperture has a few papillae on the outer edge but the inner edge is smooth (Figure $8 \mathrm{C}$ ). The adductor muscles are small (Figure $8 \mathrm{~A}$ ) and the pedal protractor muscles are very thin.

The volume of the shell is filled with the large ctenidium composed of two demibranchs with reflexed filaments, the 

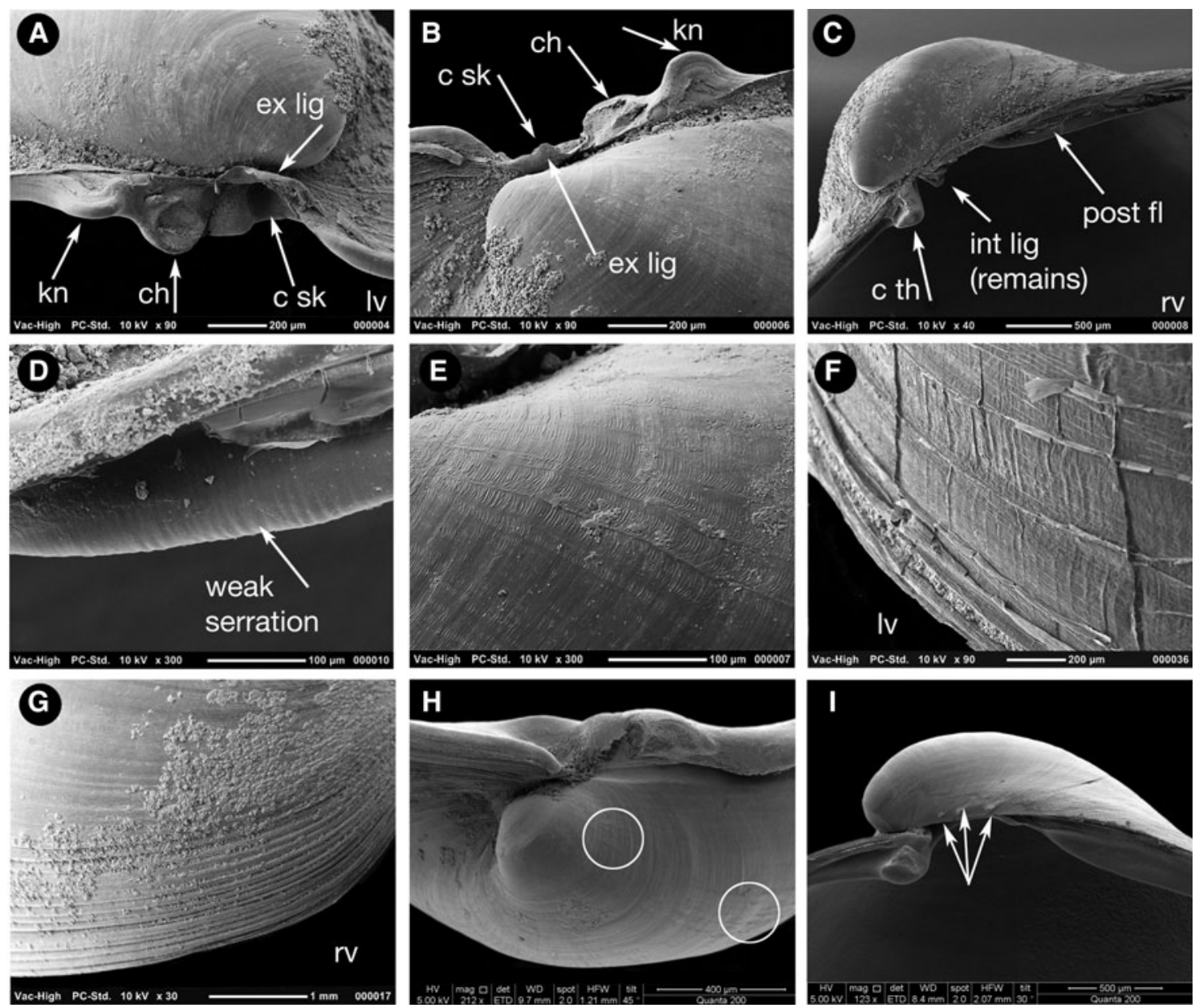

Fig. 6. Scanning electron micrographs of the shell of Apachecorbula muriatica. (A) left valve hinge; (B) dorsal view of left valve hinge; (C) right valve hinge; (D) weak serrations on the posterior flange of the right valve; (E) microsculpture on the umbonal area of the left valve; (F) radial creases in the periostracum at the margins of the left valve; $(\mathrm{G})$ commarginal ridges at the margins of the right valve; $(\mathrm{H})$ radial impressions on the shell after removal of the periostracum; small spines on the dorsal margin of the early shell.
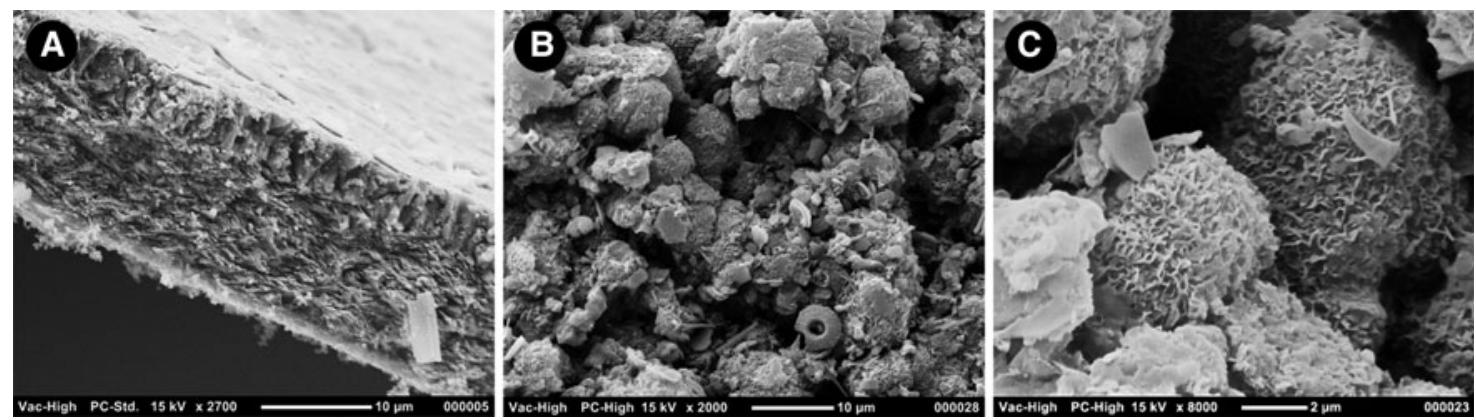

Fig. 7. Scanning electron micrographs of the shell of Apachecorbula muriatica. (A) cross section of the shell; (B, C) black surface coating showing structure as an accumulation of reticulate spherules.

outer demibranch is approximately two-thirds the size of the inner (Figure 8A, B). The filaments (Figure 9A-D) are narrow with heavily ciliated frontal surfaces (Figure $9 \mathrm{~A}$ ) and are interconnected with regularly spaced muscular junctions best seen from the abfrontal face (Figure $9 \mathrm{~B}$ ). The frontal ciliation (Figure $9 \mathrm{D}$ ) is composed of a row of frontal cilia (fc) bounded on either side by a row of lateral frontal cirri (lfc), these bounded by a row of lateral cilia (lc) that lie slightly to the posterior and are seen from the abfrontal surface. The frontal cilia give way to longer terminal cilia (tc) towards the food groove. The lateral frontal cirri appear as lamellar structures with multiple fine ends (Figure 9C) and arise from prominent ridged bases (lfc[b]), this in contrast with the frontal and terminal cilia that arise from a punctate cushion-like surface (tc[b]).

Labial palps are vestigial and lack sorting ridges

The foot and visceral mass are proportionately small compared with the mantle cavity and are contained within the anterior dorsal region (Figure 8A). The foot (Figure 8D, $\mathrm{f}$ ) has a long toe and a short heel, these separated by a small 


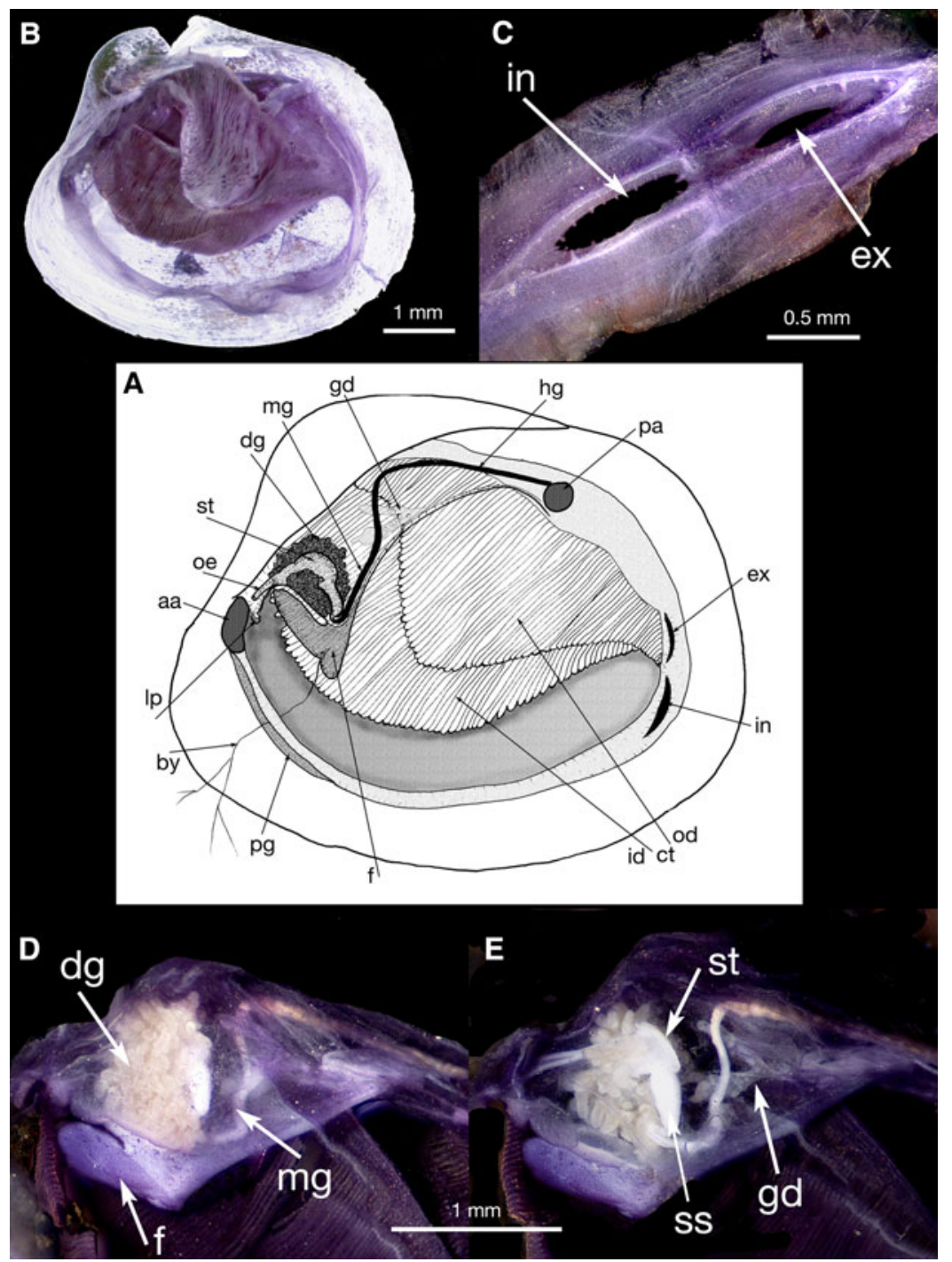

Fig. 8. Gross anatomy of Apachecorbula muriatica after dissection from the left side and stained in haematoxylin. (A) semi-diagrammatic reconstruction of the gross anatomy; (B) whole animal after removal of left valve and mantle; (C) siphonal openings; (D) visceral mass; (E) visceral mass with digestive gland and epithelium dissected away.

byssal groove. The byssus is active and produces a very fine thread that has a multiple split end (Figure $8 \mathrm{~A}$, by).

The alimentary system (Figure $8 \mathrm{~A}, \mathrm{D}, \mathrm{E}$ ) is composed of a short oesophagus (oe), a stomach (st) with two distinct parts, a dorsal cavity and a ventral tube housing the style sac (ss). The digestive diverticula ( $\mathrm{dg}$ ) are confined to the immediate surrounds of the stomach and open by a single ventral aperture into the stomach. The remainder of the gut and rectum are not coiled.

A small portion of gonadal tissue (Figure $8 \mathrm{E}, \mathrm{gd}$ ) was observed but the detailed structure and that of the heart and kidneys could not be discerned by gross dissection.

\section{ETYMOLOGY}

From the Latin muriaticus meaning 'of brine' (Brown, 1956); referring to the brine pool habitat.

\section{COMPARISONS}

Only three identified species of Corbulidae are recorded from the Red Sea, C. (Varicorbula) erythraeensis Adams, 1871 (Figure 10A, B), C. (Ansiocorbula) sulculosa Adams, 1870
(Figure $10 \mathrm{D}, \mathrm{E})$ and C. (A.) taitensis Lamarck, 1818 (Figure 10G, H) (Oliver, 1992). Unidentified species of Corbula were listed by Grill \& Zuschin (2001) and a further but undescribed species has been collected from the deep central Red Sea and is referred to here as C. (Varicorbula) sp. 1 (Figures $11 \mathrm{~A}-\mathrm{D} \& 12 \mathrm{~F}-\mathrm{I}$ ). A fifth was recorded from the Thuwal Seep and tentatively identified as $C$. $(V$.) rotalis (Batang et al., 2012), shells from the type locality of Japan are illustrated here (Figure $10 \mathrm{C}, \mathrm{F}$ ). Both species of Anisocorbula have almost equilateral heavy, strongly sculptured shells quite unlike Apachecorbula. The other three species can be assigned to the subgenus Varicorbula and have inequilateral, strongly inequivalve, robust shells with a prominent commarginal sculpture on the right valve. These characters contrast with the thin and modioliform shell of Apachecorbula. As stated under the generic remarks Apachecorbula is unlike all other corbulid genera in the weakly inequivalve, modioliform and thin shell but these are characters seen in the juvenile shells of some species. Juvenile Anisocorbula are distinctly carinate and some have a pustulose microsculpture (Figure ${ }_{12} \mathrm{C}, \mathrm{D}$ ), both characters 

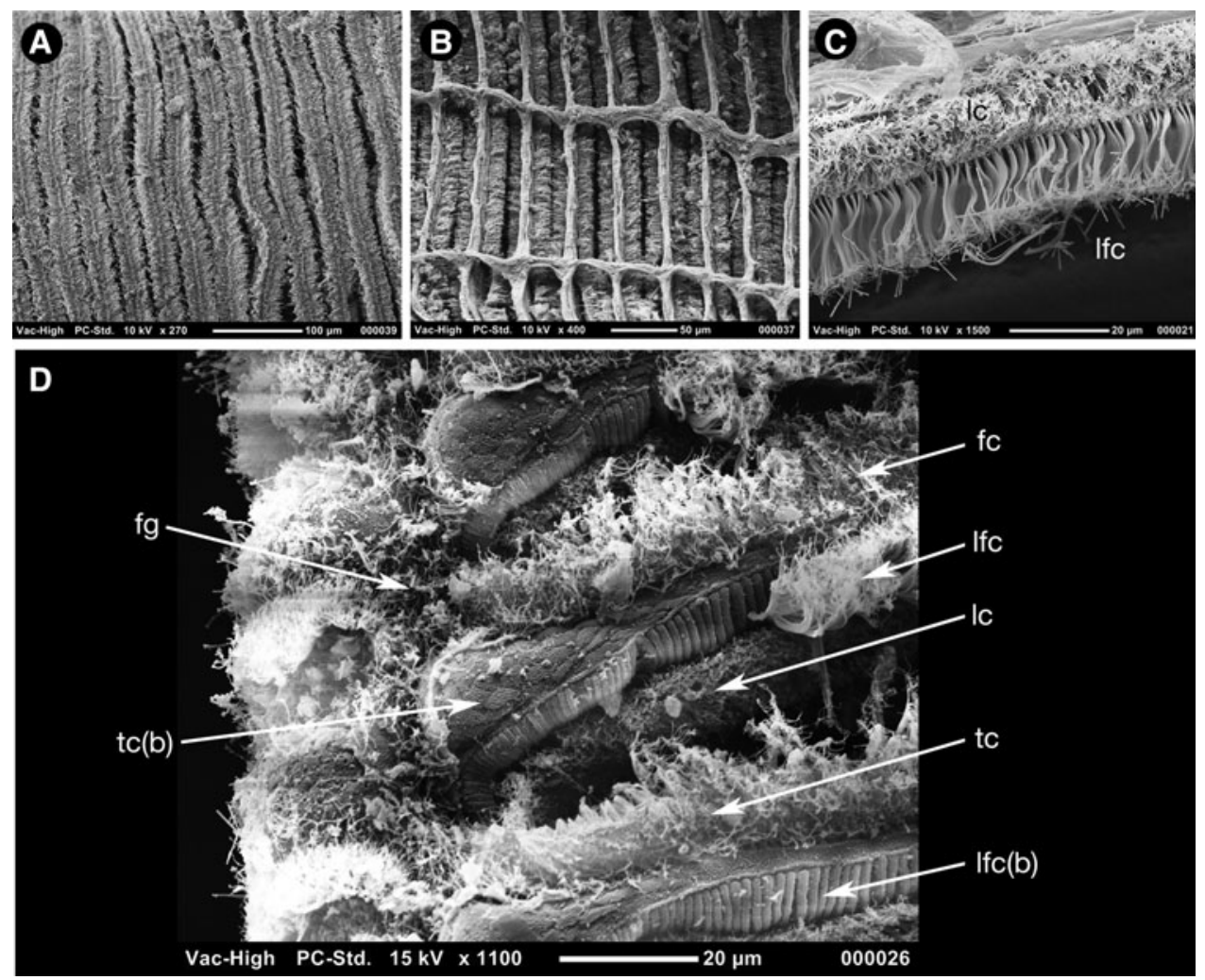

Fig. 9. Scanning electron micrographs of the ctenidium of Apachecorbula muriatica. (A) frontal surface; (B) abfrontal surface; (C) lateral frontal cirri and lateral cilia; (D) ciliation at the ventral edge of the inner demibranch.

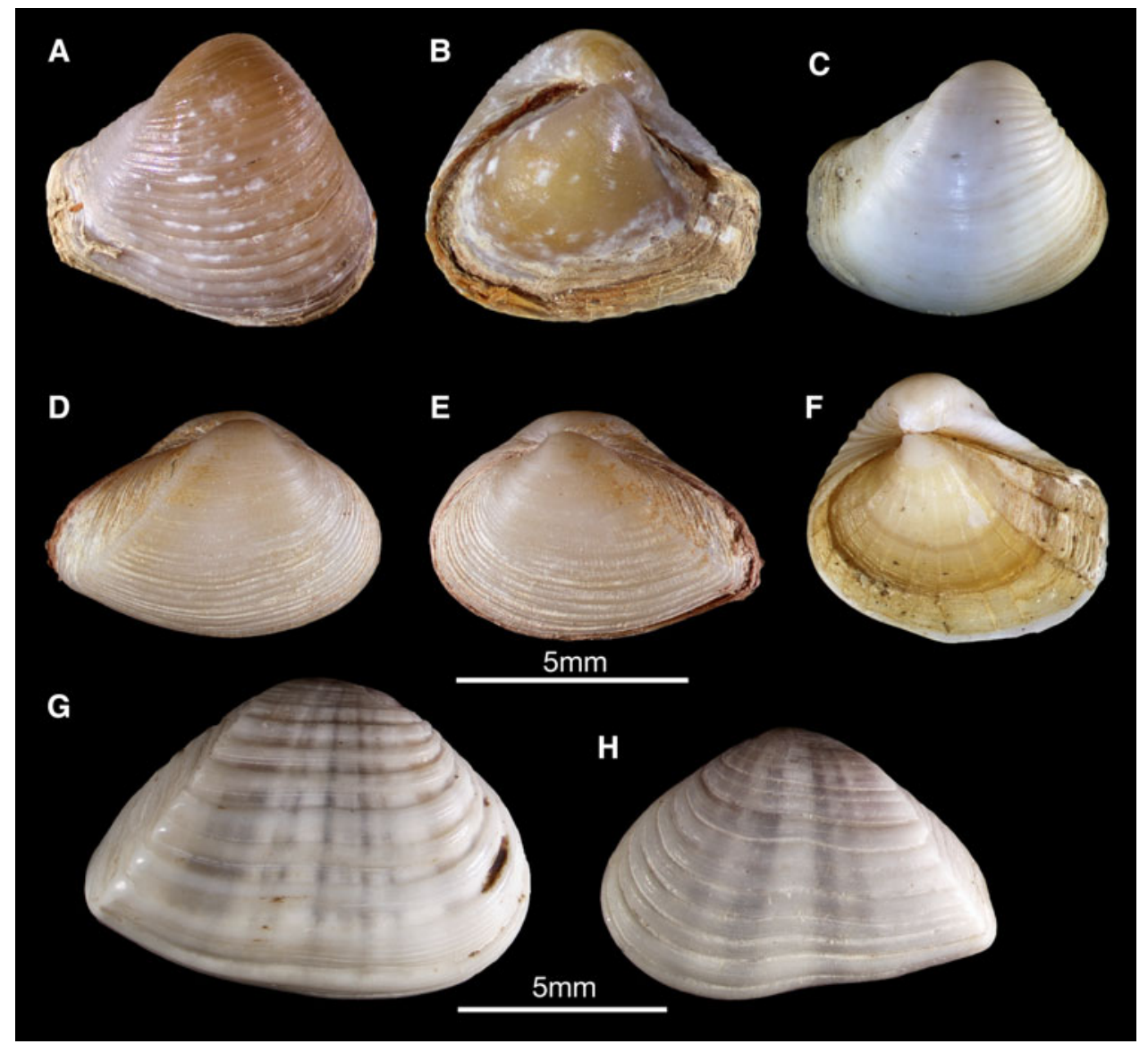

Fig. 10. Shells of Red Sea Corbulidae. (A, B), Corbula (Varicorbula) erythraeensis; (C, F), C. (V.) rotalis; (D, E), C. (Anisocorbula) sulculosa; (G, H), C. (A.) taitensis. 


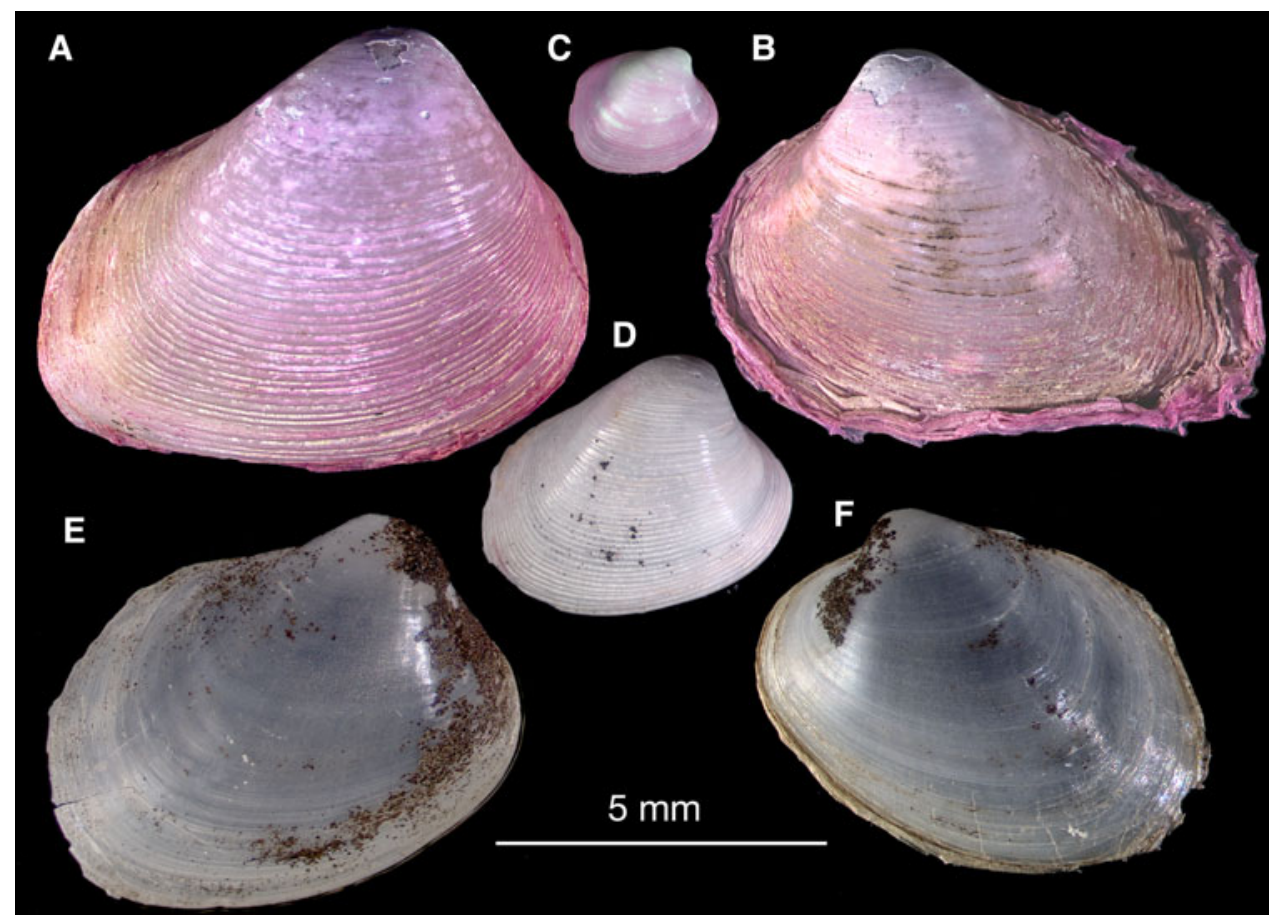

Fig. 11. (A-D) Shells of Corbula (Varicorbula) sp. 1, Central Red Sea. (E-F) Apachecorbula muriatica, large specimen for comparison.

not seen in Apachecorbula. Juveniles of Varicorbula are quadrate in outline (Figure $12 \mathrm{~A}$ ) with the anterior narrower than the posterior, with growth they become narrow, almost rostrate, posteriorly. These juveniles have a distinct umbonal angulation and are almost carinate in some, the left valve has a wide non-calcified margin and is weakly pustulose in C. $(V$.$) erythraeensis (Figure 12A, B); this in contrast with$ the smooth shell of A. muriaticus. In Varicorbula sp. 1 the ribbed sculpture of the right valve appears at an early stage, approximately at one millimetre (Figure $12 \mathrm{G}$ ) and has no radial sculptural element on the early shell (Figure $12 \mathrm{~F}$ ). The indications of dorsal spines in Apachecorbula are reminiscent of the distinct spines present in juveniles of the European C. (V.) gibba (Figure 12E). Given the differences outlined here and the relatively large size of Apachecorbula we conclude that this does not represent a juvenile of any known species. The presence of gonadal tissue also suggests that these specimens are adult.

\section{DISCUSSIDN}

\section{Functional morphology}

The footage from the ROV (Figure 3) shows that Apachecorbula is semi-infaunal with only the anterior part of the shell within the sediment. Despite the slender nature of the byssus it is a constant feature and will function to maintain this endobyssate habit. This life habit with the posterior part of the shell well above the sediment surface may account for the absence of well-developed siphons in Apachecorbula and is in contrast with the siphonate condition found in all other corbulids studied (Yonge, 1946; Morton, 1990; Mikkelsen \& Bieler, 2001). Shallow water corbulids are generally described as shallow burrowers with the posterior part of the shell lying at or close to the sediment surface (Yonge, 1946; Morton, 1990). Yonge (1946) makes reference to the heavy sediment load experienced by $C$. (V.) gibba and relates this to the form and function of the papillate siphons and the large quantities of pseudofaeces produced. Mikkelsen \& Bieler (2001) record instances of $C$. $(V$.) disparilis being epifaunal but with no fixed position, rather living among shell hash. The morphology of $C$. (V.) disparilis is essentially similar to other shallow water species and has well developed papillate siphons. The paucity of siphonal papillae in Apachecorbula may be related to the semi-infaunal habit but may also reflect the potential paucity of suspended food particles available to it.

The large gill, its ciliation and lack of gut coiling suggest that Apachecorbula is a suspension feeder. Deep-sea deposit feeding bivalves typically have coiled mid and hind guts, and large labial palps or palp probosides (Allen, 1979). There is no abfrontal extension indicative of forms harbouring chemosymbiotic bacteria (Taylor \& Glover, 2010) and no bacteriocyte cells were observed. The diversity of suspension feeding bivalves in the deep sea is limited primarily to Arcidae and Limopsidae (Oliver, 1979) and for the relatively well-studied Atlantic deep-sea fauna corbulids are all but absent from the bathyal and abyssal zones (Allen, 2008). As a suspension feeder Apachecorbula might be expected to have labial palps at least as large as other species in the family but this is not so as the palps are very small. This suggests that sorting of food particles is reduced and this is supported by the absence of guard cilia on the food groove of the ctenidium. Yonge (1946) suggested that the guard cilia in $C$. (V.) gibba functioned to prevent unwanted non-food particles being carried to the labial palps and mouth. Their absence, reduced palps and weak papillation of the inhalant aperture all suggest that Apachecorbula is not subjected to a large load of suspended particles entering the mantle cavity and does not 

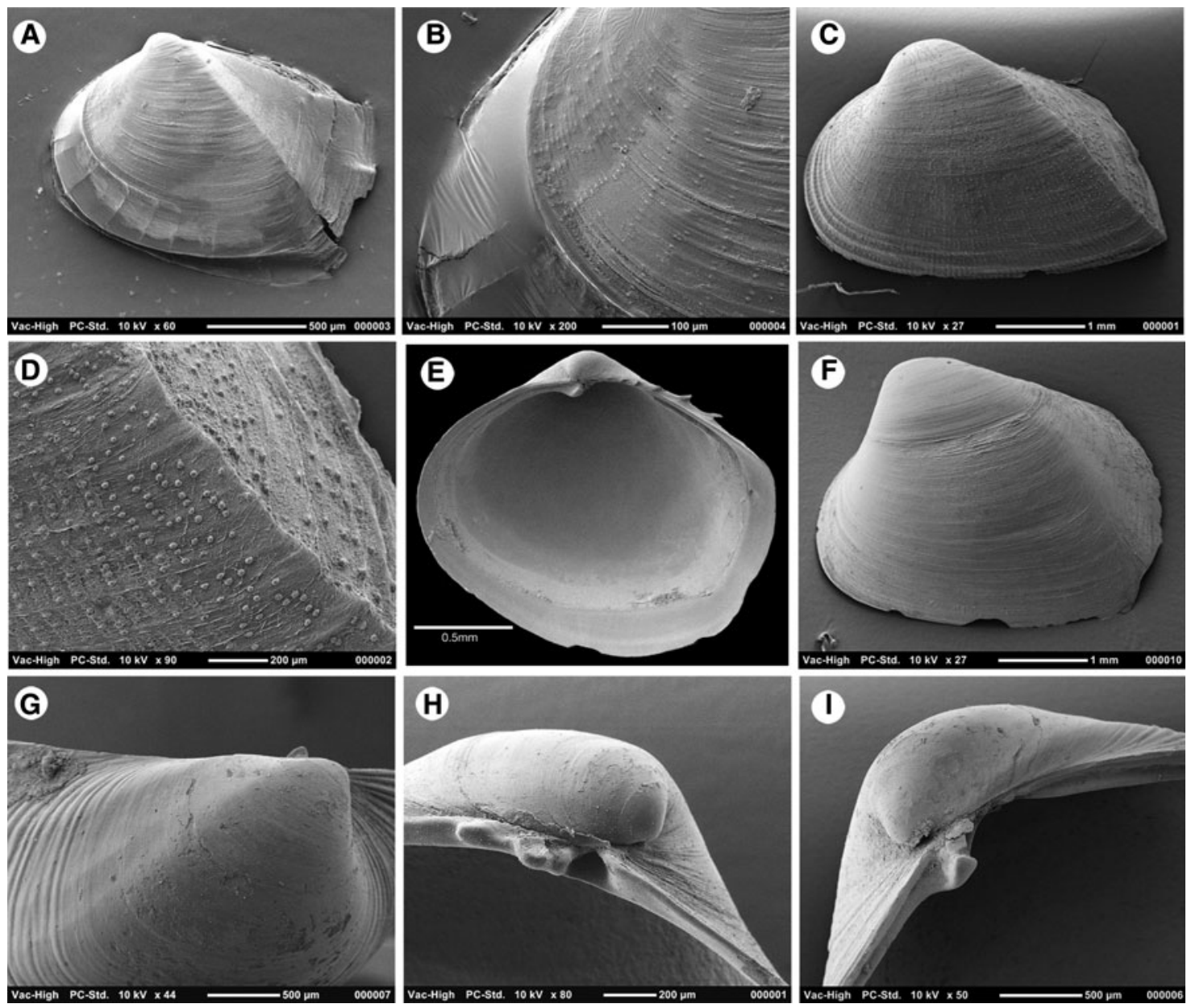

Fig. 12. Scanning electron micrographs of juvenile shells of corbulid species. (A-B) C. (V.) erythraeensis, (A) whole left valve; (B) pustules on anterior slope. (C, D), C. (A.) sulculosa (A) whole left valve; (D) posterior carina and radial rows of pustules. (E) Internal of right valve of C. (V.) gibba showing dorsal spines. (F-I) A. (V.) sp. 1 (F) whole left valve; (G) umbonal region of right valve; (H) hinge of left valve; (I) hinge of right valve.

sort particles to the same extent as shallow water species. Together this suggests that food is in short supply.

The overall appearance of the soft tissues is one of contracted size and lack of substance except for the ctenidia. We propose that the large ctenidium is maintained to facilitate both food collection and respiration in conditions of low food and low oxygen. However, these adaptations do not overcome the severe conditions and the body mass is relatively small compared with the volume of the shell thus reducing the metabolic demand. A similar low body mass was reported in Amygdalum anoxicolum, a glassy mussel from the oxygen minimum zone off Oman (Oliver, 2001).

A number of studies on corbulids note the thick shell and presence of conchioloin layers: Yonge (1946) on C. (V.) gibba from Scotland; Morton (1990) on C. crassa from Hong Kong and Mikkelsen \& Bieler (2001) on C. (V.) disparilis from Florida. The conchiolin layers are postulated to prevent predation by shell-boring gastropods, their absence in A. muriaticus suggests that such predation pressures do not exist. The thin shell reduces the energy demand for shell production especially in an environment that has a reduced $\mathrm{pH}$.

It has been noted above that the shell of Apachecorbula most resembles that of the juvenile shells of Varicorbula suggesting that paedomorphosis has occurred. The shells are relatively large $(9 \mathrm{~mm})$ compared with species that have evolved by progenesis, e.g. Turtonia minuta at $2 \mathrm{~mm}$ (Ockelmann, 1964) and Notolimea clandestina at $1 \mathrm{~mm}$ (Salas, 1994). Hayami \& Kase (1993) cited abnormal salinity, metallic cations $(\mathrm{Fe}, \mathrm{Cu})$, oxygen deficiency, high turbidity, strong water agitation, high population density, abnormal $\mathrm{pH}$, temperature variations and deficient food supply as possible causes of stunting. Many of these factors apply to the extreme environment of the rim of the brine pool yet the size is not atypically small in comparison with other Red Sea corbulids that have a maximum size of $13 \mathrm{~mm}$ in Varicorbula sp. 1 and Anisocorbula taitensis. The feeble musculature, small size of the visceral mass and small adductor muscles do however give an impression of stunting such that there is 'a small body in a large shell' appearance to Apachecorbula. The shell although not smaller is much thinner than in most corbulids and in this could be regarded as stunted. We propose that progenesis has not occurred but the extreme conditions have stunted the growth of selected tissues and organs. The large ctenidium is retained in order to maximize food particle collection and respiration, and the thin shell can reduce energy demand. The large, thin shell, which can be regarded as a neotenous character, does not increase predation pressure as predators are not abundant. Colonization of the rim of the brine pool is therefore negatively influenced by the extreme environmental parameters but 
these are partly mitigated by biological parameters such as lack of competition and few predators.

In the systematic section we noted that corbulids are infrequent in the bathyal and abyssal regions of the deep oceans across the world. The Red Sea appears to be an exception with species being recorded from the Thuwal Seep at a depth of $840-850 \mathrm{~m}$ (Batang et al., 2012) and the C. (Varicorbula) sp. 1 from $1465 \mathrm{~m}$ (this paper). Such bathymetric range extensions are not unusual for Red Sea invertebrates and it is argued that the high temperatures maintained in the deep Red Sea allow shallow warm-water taxa to exist at greater depths (Türkay, 1996). High levels of endemism are recorded for the deep Red Sea fauna (Türkay, 1996) and to date corbulids have not been recorded from depths beyond the shelf in the adjacent Gulf of Aden and Arabian Seas. The deepest records are those of Corbula subquadrata Melvill \& Standen, 1907 and C. persica Smith 1906 from $285 \mathrm{~m}$ in the Gulf of Oman (Melvill \& Standen, 1907).

Both Apachecorbula and Corbula sp. 1 can be added to the list of endemics from the Red Sea. The various environmental crises experienced by the Red Sea including periods of hypersalinity and anoxia (Braithwaite, 1987) could have simulated current brine pool conditions at shallow depths creating an adaptive force in the shallow-water fauna.

\section{ACKNOWLEDGEMENTS}

We are grateful to all help from the other Leg 4 Red Sea Expedition 2013 KAUST participants; Ioannis Georgakakis, Thor A. Klevjer, Perdana Karim Prihartato, Anders Røstad and Ingrid Solberg. Leonidas Manousakis and Manolis Kalergis from Hellenic Centre for Marine Research (HCMR) assisted in ROV operations. The captain and crew of RV 'Aegaeo' provided support during the entire cruise. Ohoud Mohammed Eid Alharbi assisted with the electron microscopy. The Red Sea Expedition 2013 was sponsored by KAUST. We also thank Ronald Janssen of the Senckenberg Institution for the loan of comparative material from the RV Meteor expeditions.

\section{REFERENCES}

Allen J.A. (1979) The adaptations and radiation of deep-sea bivalves. Sarsia $64,19-27$.

Allen J.A. (2008) Bivalvia of the Deep Atlantic. Malacologia 50, 57-173.

Anderson L.C. and Roopnarine P.D. (2003) Evolution and phylogenetic relationships of Neogene Corbulidae (Bivalvia: Myoidea) of tropical America. Journal of Paleontology 77, 1086-1102.

Anisimova M. and Gascuel O. (2006) Approximate likelihood ratio test for branches: a fast, accurate and powerful alternative. Systematic Biology 55, 539-552.

Antunes A., Ngugi D.K. and Stingl U. (2011) Microbiology of the Red Sea (and other) deep-sea anoxic brine lakes. Environmental Microbiology Reports 3, 416-433.

Batang Z.B., Papathanassiou E., Al-Suwailem A., Smith C., Salomidi M., Petihakis G., Alikunhi N.M., Smith L., Mallon F., Yapici T. and Fayad N. (2012) First discovery of a cold seep on the continental margin of the central Red Sea. Journal of Marine Systems 94, 247-253.
Bischoff J.L. (1969) Red Sea geothermal brines deposits: their mineralogy, chemistry and genesis. In Degens D.T. and Ross D.A. (eds) Hot brines and recent heavy metal deposits in the Red Sea. New York, NY: Springer Verlag, pp. 308-401.

Braithwaite C.J.R. (1987) Geology and paleogeography of the Red Sea region. In Edwards A.J. and Head S.M. (eds) Key environments: the Red Sea. Oxford: Pergamon Press, pp. 22-44

Brown R.W. (1956) Composition of scientific words. London: Smithsonian Institution Press, $882 \mathrm{pp}$

Carney S.L., Formica M.I., Divatia H., Nelson K., Fisher C.R. and Schaeffer S.W. (2006) Population structure of the mussel "Bathymodiolus" childressi from Gulf of Mexico hydrocarbon seeps. Deep Sea Research Part I 53, 1061-1072. http://dx.doi.org/10.1016/j. dsr.2006.03.002.

Castresana J. (2000) Selection of conserved blocks from multiple alignments for their use in phylogenetic analysis. Molecular Biology and Evolution 17, 540-552.

Chevenet F., Brun C., Banuls A.L., Jacq B. and Christen R. (2006) TreeDyn: towards dynamic graphics and annotations for analyses of trees. BMC Bioinformatics 7, 439

Cordes E.E., Hourdez S. and Roberts H.H. (2010) Unusual habitats and organisms associated with the cold seeps of the Gulf of Mexico. In Kiel S. (ed.) The vent and seep biota: aspects from microbes to ecosystems. Topics in geobiology, Vol. 33. Berlin: Springer, pp. 315-332.

Dereeper A., Guignon V., Blanc G., Audic S., Buffet S., Chevenet F., Dufayard J.F., Guindon S., Lefort V., Lescot M., Claverie J.M. and Gascuel O. (2008) Phylogeny.fr: robust phylogenetic analysis for the non-specialist. Nucleic Acids Research 1, 36

Edgar R.C. (2004) MUSCLE: multiple sequence alignment with high accuracy and high throughput. Nucleic Acids Research 32, 1792-1797.

Folmer O., Black M., Hoeh W., Lutz R. and Vrijenhoek R. (1994) DNA primers for amplification of mitochondrial cytochrome $\mathrm{c}$ oxidase subunit I from diverse metazoan invertebrates. Molecular Marine Biology and Biotechnology 3, 294-299.

Giribet G., Carranza S., Baguñà J., Riutort M. and Ribera C. (1996) First molecular evidence for the existence of a Tardigrada + Arthropoda clade. Molecular Biology and Evolution 13, 76-84.

Grill B. and Zuschin M. (2001) Modern shallow- to deep-water bivalve death assemblages in the Red Sea ecology and biogeography. Palaeogeography, Palaeoclimatology, Palaeoecology 168, 75-96.

Guindon S. and Gascuel O. (2003) A simple, fast, and accurate algorithm to estimate large phylogenies by maximum likelihood. Systematic Biology 52, 696-704

Gustafson R.G., Turner R.D., Lutz R.A. and Vrijenhoek R.C. (1998) A new genus and five new species of mussels (Bivalvia: Mytilidae) from deep-sea sulfide/hydrocarbon seeps in the Gulf of Mexico. Malacologia 40, 63-112.

Hallan A., Colgan D.J., Anderson L.C., García A. and Chivas A.R.A. (2013) A single origin for the limnetic-euryhaline taxa in the Corbulidae (Bivalvia). Zoologica Scripta 42, 278-287.

Hartmann M. (1985) Atlantis II deep geothermal brine system. Chemical processes between hydrothermal brines and Red Sea deep water. Marine Geology 64, 157-177.

Hayami I. and Kase T. (1993) Submarine cave bivalvia from the Ryukyu Islands: systematics and evolutionary significance. The University Museum, The University of Tokyo, Bulletin 35, 1-133.

Lampadariou N., Hatziyanni E. and Tselepides A. (2003) Community structure of meiofauna and macrofauna in Mediterranean deep-hyper-saline anoxic basins: CIESM, 2003. Mare Incognitum? Exploring Mediterranean deep-sea biology. CIESM Workshop 
Monographs no 23, 128 pages, Monaco. www.ciesm.org/publications/ Herakliono3.pdf.

Lorion J., Buge B., Cruaud C. and Samadi S. (2010) New insights into diversity and evolution of deep-sea Mytilidae (Mollusca: Bivalvia). Molecular Phylogenetics and Evolution 57, 71-83.

MacDonald I.R., Guinasso H.L., Reilly Brooks J.M., Callender W.R. and Gabrielle S.G. (1990) Gulf of Mexico hydrocarbon seep communities. VI. Patterns in community structure and habitat. Geo-Marine Letters 10, 244-252.

Melvill J.C. and Standen R. (1907) The Mollusca of the Persian Gulf, Gulf of Oman and Arabian Sea, as evidenced mainly through the collections of Mr. F. W. Townsend, 1893-1906; with descriptions of new species. Part II. - Pelecypoda. Proceedings of the Zoological Society of London 1906, 783-848.

Mikkelsen P.M. and Bieler R. (2001) Varicorbula (Bivalvia: Corbulidae) of the western Atlantic: taxonomy, anatomy, life habits, and distribution. The Veliger 44, 271-293.

Morton B. (1990) The biology and functional morphology of Corbula crassa (Bivalvia: Corbulidae) with special reference to shell structure and formation. In Morton B. (ed.) The marine flora and fauna of Hong Kong and Southern China II. Volume 3. Behaviour, morphology, physiology and pollution. Hong Kong: Hong Kong University Press, pp. 1055-1073.

Ockelmann K.W. (1964) Turtonia minuta (Fabricius), A neotenous veneracean bivalve. Ophelia 1, 121-146.

Oliver P.G. (1979) Adaptations of some deep-sea suspension feeding bivalves (Limopsis and Bathyarca). Sarsia 64, 33-36.

Oliver P.G. (1992) The Bivalve Seashells of the Red Sea. An Identification Guide. Christa Hemmen Verlag, Wiesbaden \& The National Museum of Wales, Cardiff. 33opp., 46 col. pls.

Oliver P.G. (2001) Functional morphology and description of a new species of Amygdalum (Mytiloidea) from the oxygen minimum zone of the Arabian Sea. Journal of Molluscan Studies 67, 225-241.
Salas C. (1994) Notolimea clandestina a new species of neotenous bivalve (Bivalvia: Limidae) endemic to the Strait of Gibraltar. Journal of Molluscan Studies 63, 249-254.

Taylor J.D. and Glover E.A. (2010) Chemosymbiotic bivalves. In Kiel S (ed.) The vent and seep biota: aspects from microbes to ecosystems. Topics in geobiology, Vol. 33. Berlin: Springer, pp. 107-135.

Türkay M. (1996) Composition of the deep Red Sea macro- and megabenthic invertebrate fauna. Zoogeographic and ecological implications. In Uiblein F., Ott J. and Stachowitsch M. (eds) Deep-sea and extreme shallow-water habitats: affinities and adaptations. Biosystematics and ecology, Series 11. Vienna: Austrian Academy of Sciences, pp. 43-59.

Whiting M.F., Carpenter J.C., Wheeler Q.D. and Wheeler W.C. (1997) The Strepsiptera problem: phylogeny of the holometabolous insect orders inferred from $18 \mathrm{~S}$ and $28 \mathrm{~S}$ ribosomal DNA sequences and morphology. Systematic Biology 46, 1-68.

Xiong B. and Kocher T.D. (1991) Comparison of mitochondrial DNA sequences of seven morphospecies of black flies (Diptera: Simuliidae). Genome 34, 306-311.

Yonge C.M. (1946) On the habits and adaptations of Aloidis (Corbula) gibba. Journal of the Marine Biological Association of the United Kingdom 26, 358-376.

and

Zierenberg R.A. and Shanks W.C. III (1986) Isotopic constraints on the origin of the Atlantis II, Suakin and Valdivia brines, Red Sea. Geochimica et Cosmochimica Acta 50, 2205-2214.

\section{Correspondence should be addressed to:} P.G. Oliver

National Museum of Wales, Cathays Pk., Cardiff CF10 3 NP, Wales, UK email: graham.oliver@museumwales.ac.uk 